\title{
Fenoprofen Calcium
}

National Cancer Institute

\section{Source}

National Cancer Institute. Fenoprofen Calcium. NCI Thesaurus. Code C61761.

The calcium salt form of fenoprofen, a propionic acid derivative with analgesic, nonsteroidal antiinflammatory and antirheumatic properties. Fenoprofen inhibits both isozymes of cyclooxygenase; resulting in prostaglandin synthesis inhibition, thereby blocking the conversion of arachidonic acid to prostaglandins. In addition, fenoprofen activate both peroxisome proliferator activated receptors (PPAR)-alpha and -gamma, by which it may down-regulate leukotriene B4 production. 